\title{
Effect of Al Substitution on the Electronic and Magnetic Properties of $\mathrm{GdCo}_{5}$
}

\author{
A. SzajeK* AND W.L. MaLinowski \\ Institute of Molecular Physics, Polish Academy of Sciences \\ Smoluchowskiego 17, 60-179 Poznań, Poland
}

(Received September 19, 2001; revised version February 7, 2002)

Experimental data show that aluminium doped RCo5 systems crystallize in $\mathrm{CaCu}_{5}$-type structure for most of the rare-earth elements (R). Al impurities randomly occupy one of the two possible positions (2c and $3 \mathrm{~g}$ ) and there is a critical concentration of $\mathrm{Al}, x_{\mathrm{c}}=2.0$, for $\mathrm{RCo}_{-x} \mathrm{Al}_{x}$ when the Co sublattice becomes nonmagnetic. The ab initio self-consistent calculations show strong dependence of magnetic properties of $\mathrm{GdCo}_{-} \mathrm{Al}_{x}$ on concentration of $\mathrm{Al}$ and position of the impurities in the unit cell, furthermore to fulfil experimental observation of existence of critical concentration, $x_{\mathrm{C}}=2.0$, the $\mathrm{Al}$ impurities should prefer $3 \mathrm{~g}$ positions otherwise the magnetic moments on Co atoms do not vanish.

PACS numbers: 71.20.-b, 71.20.Eh

\section{Introduction}

Intermetallic compounds of rare-earth ( $\mathrm{R}$ ) atoms and transition-metal ( $\mathrm{T}$ ) atoms are of great importance both for the technological applications and from fundamental physical point of view. First, the strongest permanent magnets belong to this class of materials and some of them are promising materials for use in batteries because of their special electrochemical properties. Second, they represent a big challenge for the electron theory because their properties are determined by two different types of electronic states, i.e. the highly correlated and strongly

*corresponding author; e-mail: szajek@ifmpan.poznan.pl 
localized $4 f$ states of rare-earth atoms and the valence states of transition-metal atoms which are comparatively weakly correlated and more delocalized.

Generally, in the $\mathrm{R}-\mathrm{T}$ compounds, there are three types of exchange interactions: $\mathrm{T}-\mathrm{T}$ interactions between magnetic moments of the $\mathrm{T}$ sublattice, the $\mathrm{R}-\mathrm{T}$ intersublattice interactions and the $\mathrm{R}-\mathrm{R}$ interactions between the magnetic moments within the $\mathrm{R}$ sublattice. These interactions lead to the $\mathrm{R}(5 d)-\mathrm{T}(3 d)$ hybridization. Introduction of a metalloid $(\mathrm{M}=\mathrm{B}, \mathrm{Al}$ or $\mathrm{Ga})$ to the $\mathrm{R}-\mathrm{T}$ system causes additional hybridization $\mathrm{T}(3 d)-\mathrm{M}(p)$ and $\mathrm{R}(5 d)-\mathrm{M}(p)$.

$\mathrm{R}\left(\mathrm{T}_{1-x} \mathrm{M}_{x}\right)_{5}$ is a one of the most intensively examined systems, where $\mathrm{R}$ is rare-earth metal, $\mathrm{T}=\mathrm{Co}$ or $\mathrm{Ni}$, and $\mathrm{M}=\mathrm{B}, \mathrm{Al}$ or Ga. The initial $\mathrm{RT}_{5}$ system has hexagonal $(P 6 / \mathrm{mmm}) \mathrm{CaCu}_{5}$-type structure having two inequivalent positions of $\mathrm{T}$ atoms: $2 \mathrm{c}$ and $3 \mathrm{~g}$ (see Fig. 1). Especially intensively examined were $\mathrm{R}\left(\mathrm{Co}_{1-x} \mathrm{~B}_{x}\right)_{5}$ because they form an interesting series of crystal structures (see [1] and references therein) which can be expressed by a general formula $\mathrm{R}_{n+1} \mathrm{Co}_{3 n+5} \mathrm{~B}_{2 n}(n=0$, $1,2, \ldots, \infty)$. Although the systems have uniaxial symmetry, their Curie temperatures and saturation magnetization are too low to be suitable for permanent magnet applications [2-4]. In order to overcome this drawback new series of compounds $\mathrm{R}_{m+1} \mathrm{Co}_{5 m+3} \mathrm{~B}_{2}$ with high Co content was proposed [5-8]. The mentioned above two homologous series can be expressed by a generalized formula $\mathrm{R}_{m+n} \mathrm{Co}_{5 m+3 n} \mathrm{~B}_{2 n}$, which is formed by alternative stacking of $m$ parts of $\mathrm{RCo}_{5}$ with $n$ parts of $\mathrm{RCo}_{3} \mathrm{~B}_{2}$ along the $c$ axis.

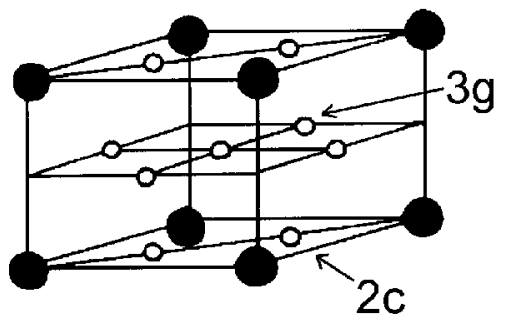

Fig. 1. CaCus-type unit cell. Small circles describe Co and $\mathrm{Al}$ atoms occupying $2 \mathrm{c}$ and $3 \mathrm{~g}$ positions. La atoms occupy $1 \mathrm{a}$ positions described by large circles.

$\mathrm{La}\left(\mathrm{Ni}_{1-x}(\mathrm{Al}, \mathrm{Co})_{x}\right)_{5}$ systems and their hydrides were examined as potential materials for batteries. Hydrogen storage alloys based on La are commercially used as negative electrode materials for nickel-metal hydride $\left(\mathrm{Ni}-\mathrm{MH}_{x}\right)$ battery [9-12]. These materials combine a high reversible energy storage capacity with fast electrochemical activation, excellent long-term cycling stability and good charge/discharge kinetics. In these alloys the initial $\mathrm{CaCu}_{5}$-type structure is conserved and the neutron diffraction measurements as well as the total energy ab initio calculations [13-15] showed that $\mathrm{Al}$ and Co impurities prefer the $3 \mathrm{~g}$ positions. Similar results were also obtained for $\mathrm{LaNi}_{5-x} \mathrm{~T}_{x}(\mathrm{~T}=\mathrm{Fe}$ or $\mathrm{Mn})$ $[16,17]$. 
The $\mathrm{X}$-ray analysis revealed that also $\mathrm{R}\left(\mathrm{Co}_{1-x} \mathrm{Al}_{x}\right)_{5}$ alloys with $x<0.3$ are single phase, occur in the $\mathrm{CaCu}_{5}$ structure, and the intensities of the X-ray lines showed that $\mathrm{Al}$ atoms randomly occupy the Co sites. Al substitutions for Co in $\mathrm{RCO}_{5}$ brings three important effects on the magnetic properties of $\mathrm{RCO}_{5}$ [18]: a decrease in the Curie temperature $\left(T_{\mathrm{C}}\right)$ and magnetic moments of Co atoms $\left(\mu_{\mathrm{Co}}\right)$, and a change of magnetic anisotropy. The $T_{\mathrm{C}}$ and $\mu_{\mathrm{Co}}$ vanish at a critical concentration of Al, $x_{c}=0.4$. Similar situation is for $\mathrm{RCo}_{3} \mathrm{~B}_{2}$.

The aim of this paper is to investigate relation between different positions of $\mathrm{Co}$ and $\mathrm{Al}$ atoms in $\mathrm{Gd}\left(\mathrm{CO}_{1-x} \mathrm{Al}_{x}\right)_{5}$ systems $(x=0,0.2$, and 0.4$)$ and their magnetic properties based on the spin polarized $a b$ initio calculations.

\section{Computational method}

The electronic structure was calculated based on the tight-binding linear muffin-tin orbital (TB LMTO) method in the atomic sphere approximation (ASA) $[19,20]$. In the ASA the unit cell is filled by Wigner-Seitz spheres having the same total volume: $(4 \pi / 3) \sum_{j} S_{j}^{3}=N(4 \pi / 3) S_{\mathrm{av}}^{3}=V$, where $j(j=1, \ldots N)$ is the index of atom in the unit cell, $N$ is number of atoms in the cell, $S_{j}$ is the Wigner-Seitz radius of the $j$-th atom, $S_{\mathrm{av}}$ is the average Wigner-Seitz radius, $V$ is the volume of the unit cell. In our case the unit cell contains one formula unit ( $N=5$ atoms). The hexagonal unit is presented in Fig. 1.

The coordinates of the atoms in the unit cell were taken from [6] and are summarized in Table I. The overlap volume of the muffin-tin spheres is about $8.2 \%$. The standard combined correction terms [19] for overlapping were used to compensate for errors due to the ASA. The scalar relativistic approximation for band electrons and the fully relativistic treatment for the frozen core electrons were used. The spin-orbit interactions were taken into account in the form proposed by Min and Jang [21]. The exchange correlation potential was assumed in the form proposed by von Barth and Hedin (BH) [22] and, for comparison, by Perdew et al. (PW) [23] with non-local corrections. The starting atomic configurations were taken as: core $+4 f^{7} 5 d^{1} 6 s^{2}$ for $\mathrm{Gd}$, core $+3 d^{7} 4 s^{2}$ for Co and core $+3 s^{2} 3 p^{1}$ for $\mathrm{Al}$ atom. The spin-polarized calculations were performed for the experimental values of the lattice constants [18] and for all possible positions of $\mathrm{Al}$ impurities in the unit cell. In the case of $\mathrm{GdCo}_{4} \mathrm{Al}$ the single $\mathrm{Al}$ atoms are located in $3 \mathrm{~g}$ and $2 \mathrm{c}$ positions one after another. For $\mathrm{GdCo}_{3} \mathrm{Al}_{2}$ the situation is more complicated and all possible configurations were considered: two $\mathrm{Al}$ atoms in $2 \mathrm{c}$ or $3 \mathrm{~g}$ positions, and a mixed situation, where the impurities are located in $2 \mathrm{c}$ and $3 \mathrm{~g}$ sites. The crystallographic characteristics are collected in Table I. The self-consistent calculations were performed for at least $9248 k$-points in the whole Brillouin zone. The number of $k$-points was dependent on the symmetry of considered systems, determined by positions of Al impurities in the unit cell. The tetrahedron method [24-26] was used for integration over the Brillouin zone. The iterations were repeated until the 
TABLE I

Crystallographic characteristics of $\mathrm{GdCo}_{5}, \mathrm{GdCO}_{4} \mathrm{Al}$, and $\mathrm{GdCO}_{3} \mathrm{Al}_{2}$ compounds: the lattice constants $a$ and $c$, the Wigner-Seitz radii (in a.u., average, $S_{\mathrm{av}}$, and for particular atoms). The lattice constants for $\mathrm{GdCo}_{3} \mathrm{Al}_{2}$ were extrapolated from experimental data for smaller concentrations of $\mathrm{Al}$.

\begin{tabular}{|c|c|c|c|c|c|c|}
\hline \multirow{5}{*}{$\begin{array}{l}\text { Positions and } \\
\text { [coordinates] } \\
\text { of atoms }\end{array}$} & \multicolumn{6}{|c|}{ Lattice constants and Wigner-Seitz radii used in calculations } \\
\hline & $\mathrm{GdCO}_{5}$ & \multicolumn{2}{|c|}{$\mathrm{GdCO}_{4} \mathrm{Al}$} & \multicolumn{3}{|c|}{$\mathrm{GdCO}_{3} \mathrm{Al}_{2}$} \\
\hline & $a=9.39950$ & \multirow{3}{*}{\multicolumn{2}{|c|}{$\begin{array}{c}a=9.49399 \\
c=7.60993 \\
S_{\mathrm{av}}=2.86983\end{array}$}} & \multirow{3}{*}{\multicolumn{3}{|c|}{$\begin{array}{c}a=9.59520 \\
c=7.69788 \\
S_{\mathrm{av}}=2.90128\end{array}$}} \\
\hline & $c=7.52678$ & & & & & \\
\hline & $S_{\mathrm{av}}=2.84034$ & & & & & \\
\hline $3 g-1$ & $\mathrm{Co}$ & $\mathrm{Al}$ & $\mathrm{Co}$ & $\mathrm{Al}$ & $\mathrm{Al}$ & Co \\
\hline$[1 / 2,1 / 2,1 / 2]$ & 2.6463 & 2.6965 & 2.6527 & 2.7264 & 2.7053 & 2.6818 \\
\hline $3 g-2$ & $\mathrm{Co}$ & $\mathrm{Co}$ & $\mathrm{Co}$ & $\mathrm{Al}$ & Co & $\mathrm{Co}$ \\
\hline$[1 / 2,0,1 / 2]$ & 2.6463 & 2.6965 & 2.6527 & 2.7264 & 2.7053 & 2.6818 \\
\hline $3 g-3$ & $\mathrm{Co}$ & $\mathrm{Co}$ & $\mathrm{Co}$ & $\mathrm{Co}$ & $\mathrm{Co}$ & $\mathrm{Co}$ \\
\hline$[0,1 / 2,1 / 2]$ & 2.6463 & 2.6965 & 2.6527 & 2.7264 & 2.7053 & 2.6818 \\
\hline $2 c-1$ & $\mathrm{Co}$ & $\mathrm{Co}$ & $\mathrm{Al}$ & $\mathrm{Co}$ & $\mathrm{Al}$ & $\mathrm{Al}$ \\
\hline$[2 / 3,1 / 3,0]$ & 2.6518 & 2.6320 & 2.7285 & 2.6632 & 2.7107 & 2.7611 \\
\hline $2 c-2$ & $\mathrm{Co}$ & $\mathrm{Co}$ & $\mathrm{Co}$ & $\mathrm{Co}$ & $\mathrm{Co}$ & $\mathrm{Al}$ \\
\hline$[1 / 3,2 / 3,0]$ & 2.6518 & 2.6320 & 2.7285 & 2.6632 & 2.7107 & 2.7611 \\
\hline $1 \mathrm{a}$ & $\mathrm{Gd}$ & $\mathrm{Gd}$ & Gd & $\mathrm{Gd}$ & $\mathrm{Gd}$ & $\mathrm{Gd}$ \\
\hline$[0,0,0]$ & 3.5457 & 3.5966 & 3.5617 & 3.6331 & 3.6164 & 3.5976 \\
\hline
\end{tabular}

energy eigenvalues of the consecutive iteration steps were the same within an error $0.01 \mathrm{mRy}$.

\section{Results and discussion}

The TB LMTO ASA method allows differentation of the ions in the cell but effect of disorder due to Al substitution is neglected. In the case of the Haucke-type phase $\mathrm{GdCo}_{5}$ (see Fig. 1 and Table I), two types of Co sites must be distinguished: the 2-fold degenerate basal sites (2c) located in the basal plane together with Gd atoms and 3 -fold degenerate non-basal sites ( $3 \mathrm{~g}$ ) located in the plane with $z=1 / 2$. In accordance with experimental observations for $\mathrm{LaNi}_{5}$ [27] and $\mathrm{GdCo}_{5}$ [18], it is assumed that the $\mathrm{Gd}$ sites do not accommodate $\mathrm{Co}$ and $\mathrm{Al}$ atoms. The total densities of states (DOS) and local contributions of individual atoms are presented in Figs. 2-7. The electronic structure of $\mathrm{GdCo}_{5}$ was calculated earlier by other authors $[28,29]$. These calculations were performed using different methods but they are consistent with ours. Therefore we treat our calculations for this system as reference results for the doped compounds to avoid discussion on differences which can be caused by distinct approaches and technical details. 


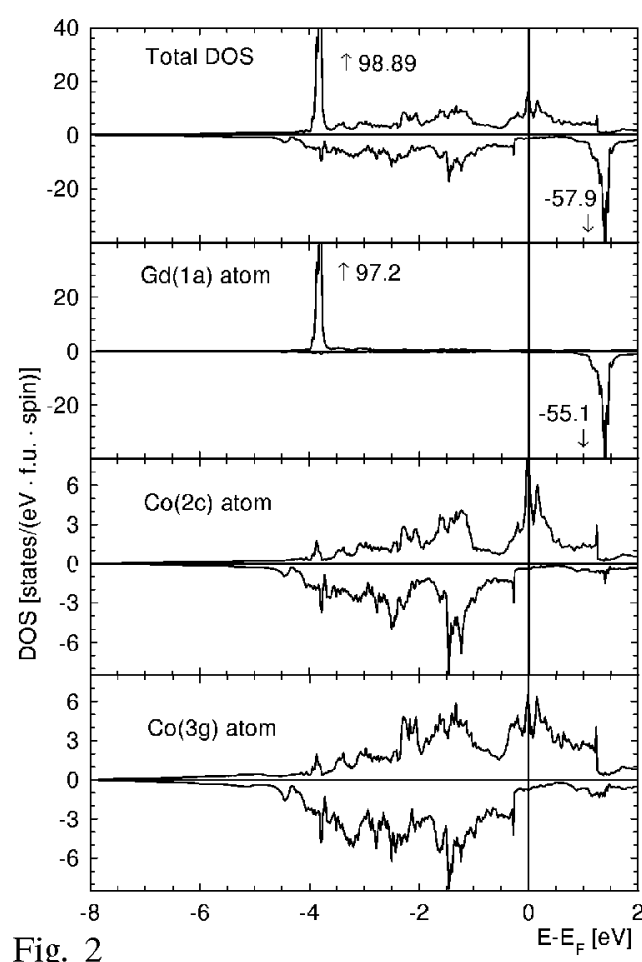

Fig. 2

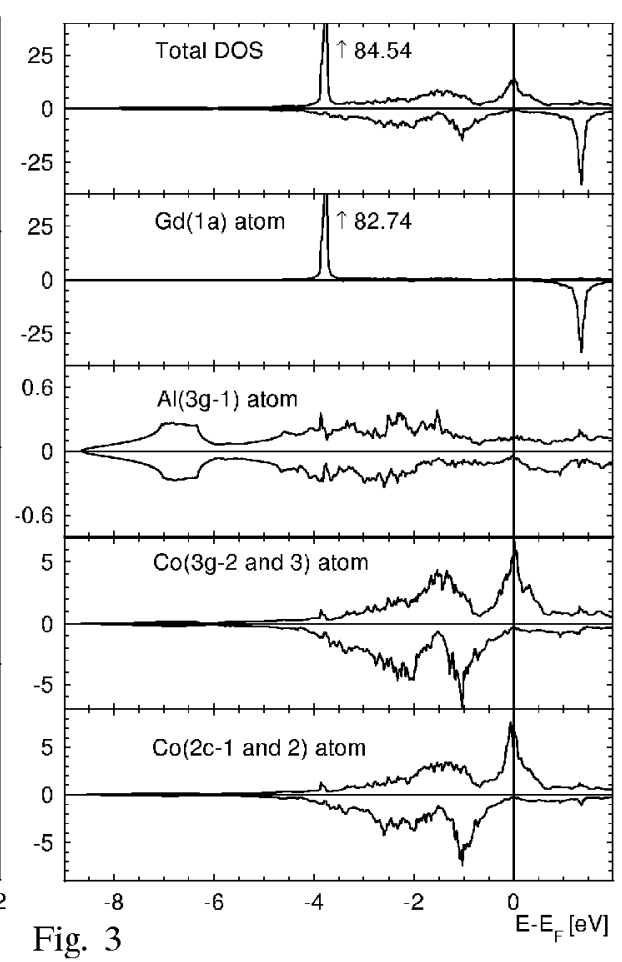

Fig. 3

Fig. 2. The total and site-projected DOS functions for the $\mathrm{GdCO}_{5}$ compound.

Fig. 3. The total and site-projected DOS functions for the $\mathrm{GdCo}_{4} \mathrm{Al}$ compound for $\mathrm{Al}$ located in $3 \mathrm{~g}-1$ position.

The width of the valence band of the $\mathrm{GdCo}_{5}$ system is about $7.9 \mathrm{eV}$. The valence bands for $\mathrm{GdCo}_{4} \mathrm{Al}$ and $\mathrm{GdCo}_{3} \mathrm{Al}_{2}$ are wider, by about 0.8 and $1.3 \mathrm{eV}$, respectively. It is caused by the $\mathrm{Al}$ atoms, their $s$ and $p$ electrons are located near the bottom of the valence band. The valence bands of the doped systems are wider than for the undoped case and because of reduced number of valence electrons (see Table II) the values of DOS at the Fermi level should also be lower.

It is generally true but strongly depends on the location of the $\mathrm{Al}$ impurities (see Table III).

The impurities cause charge transfer between ions: from $\mathrm{Al}$ to $\mathrm{Co}$ and $\mathrm{Gd}$ atoms. Electron transfer to Co atoms fulfils $d$ band and reduces their magnetic moments (see Table IV).

The $\mathrm{Al}$ atoms cause reconstruction of the starting $\mathrm{GdCo}_{5}$ band structure and change the values of DOS at the Fermi level. The DOS $\left(E=E_{\mathrm{F}}\right)$ for $\mathrm{GdCo}_{5}$ is equal to about 15.81 states/(eV f.u.) with about $95 \%$ contribution of Co atoms (2.318 and 4.04 states/(eV atom) for $\mathrm{Co}(3 \mathrm{~g})$ and $\mathrm{Co}(2 \mathrm{c})$ atoms, respectively).

For $\mathrm{GdCo}_{4} \mathrm{Al}$ systems the values of $\operatorname{DOS}\left(E_{\mathrm{F}}\right)$ decrease and reach 12.036 and 8.554 states/(eV f.u.) for impurities located in $3 \mathrm{~g}$ and $2 \mathrm{c}$ sites, respectively. In both 

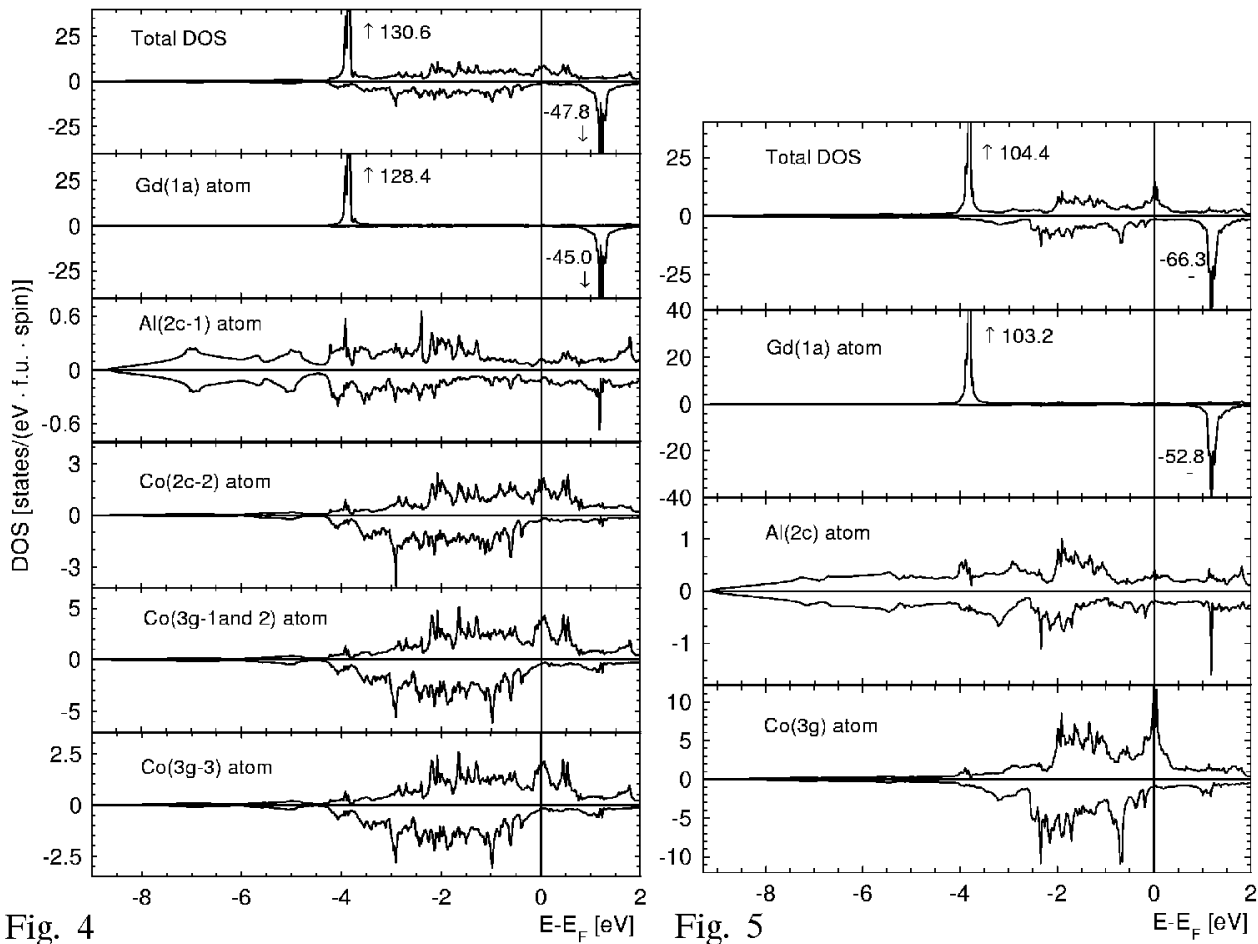

Fig. 4. The total and site-projected DOS functions for the $\mathrm{GdCo}_{4} \mathrm{Al}$ compound for $\mathrm{Al}$ atom located in $2 \mathrm{c}-1$ position.

Fig. 5. The total and site-projected DOS functions for the $\mathrm{GdCo}_{3} \mathrm{Al}_{2}$ compound for two atoms of $\mathrm{Al}$ located in $2 \mathrm{c}$ positions. The Fermi level is located in the high peak of DOS formed by the $\operatorname{Co}(d)$ electrons. In this configuration the $\operatorname{DOS}\left(E=E_{\mathrm{F}}\right)$ and the magnetic moments on Co atoms reach the highest values (see Table III and IV).

cases the highest values of magnetic moments for Co atoms were obtained in nearest neighbouring of $\mathrm{Al}$ atoms. Similar phenomenon was observed for $\mathrm{R}\left(\mathrm{Co}_{1-x} \mathrm{Al}_{x}\right)_{2}$ $(\mathrm{R}=$ rare-earth or yttrium atom), where small concentrations (about $10 \%)$ of $\mathrm{Al}$ atoms increase the Curie temperatures of these compounds [30]. In the case of $\mathrm{GdCo}_{4.5} \mathrm{Al}_{0.5}$ the mean magnetic moment for $\mathrm{Co}$ is higher than for undoped system $[18,31]$.

For the $\mathrm{GdCo}_{4} \mathrm{Al}$ system and the $\mathrm{BH}$ potential the calculated mean magnetic moments for Co atoms are equal to 1.053 and $1.122 \mu_{\mathrm{B}} / \mathrm{Co}$ atom for $\mathrm{Al}$ atoms located in $3 \mathrm{~g}$ and $2 \mathrm{c}$ sites, respectively. The second value is closer to the experimental result, which varies from 1.25 to $1.43 \mu_{\mathrm{B}}[18,31,32]$. Similarly is for the calculations with the PW potential but the values are slightly higher: 1.140 and $1.202 \mu_{\mathrm{B}} / \mathrm{Co}$ atom, respectively. Small magnetic moments, about $0.1 \mu_{\mathrm{B}}$ /atom, parallel oriented to the Gd ones, are induced on $\mathrm{Al}$ atoms. The moments on Co atoms have opposite directions to the moments located on Gd ones. The differ- 

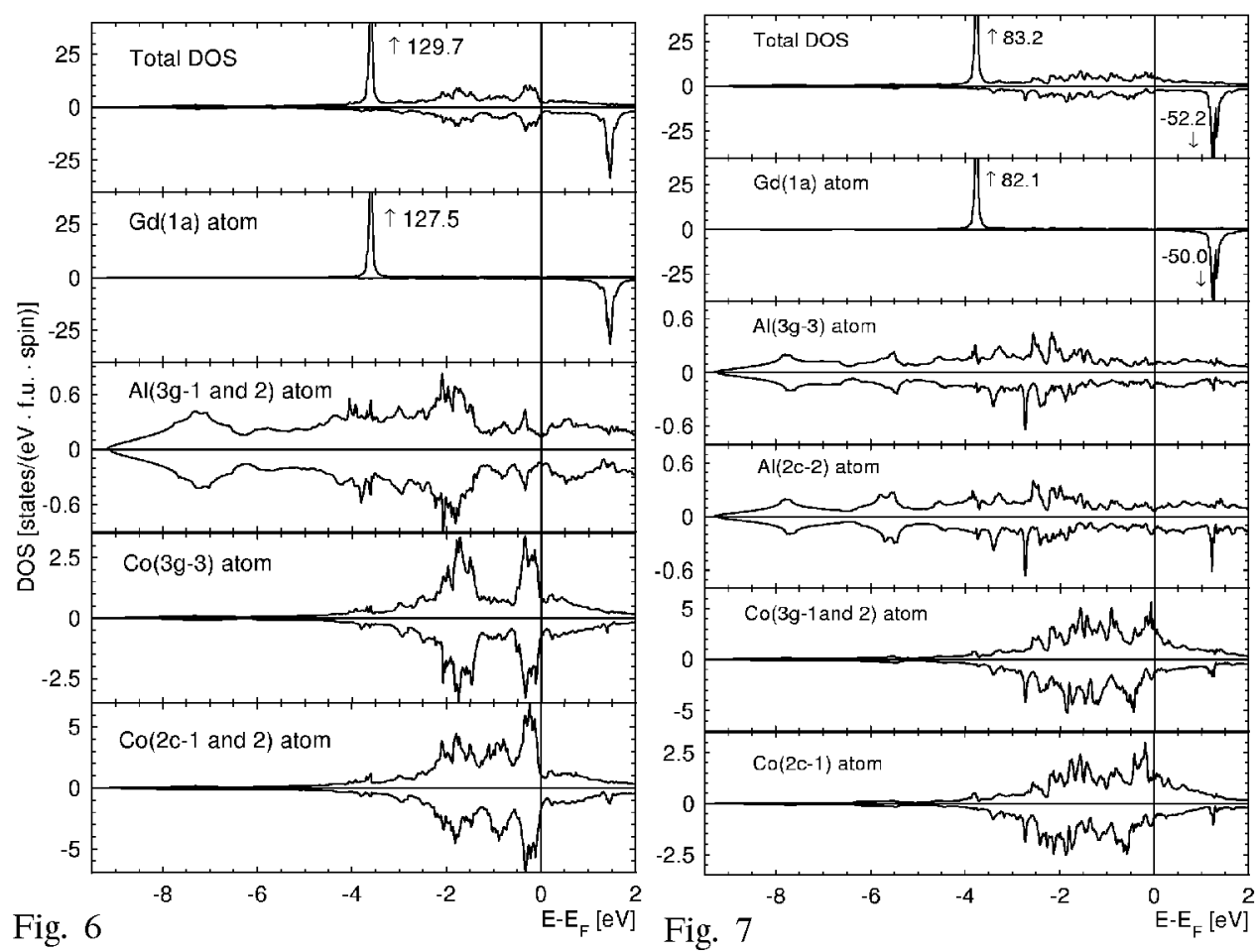

Fig. 6. The total and site-projected DOS functions for the $\mathrm{GdCo}_{3} \mathrm{Al}_{2}$ compound for two atoms of $\mathrm{Al}$ located in $3 \mathrm{~g}-1$ and $3 \mathrm{~g}-2$ positions. The Fermi level is located above the peaks formed by $\operatorname{Co}(d)$ electrons. The values of $\operatorname{DOS}\left(E=E_{\mathrm{F}}\right)$ reach the lowest values and the magnetic moments on Co atoms are close to zero.

Fig. 7. The total and site-projected DOS functions for the $\mathrm{GdCo}_{3} \mathrm{Al}_{2}$ compound for two atoms of $\mathrm{Al}$ located in $3 \mathrm{~g}-3$ and $2 \mathrm{c}-2$ positions. An intermediate situation to the presented in Figs. 5 and 6 . The Co magnetic moments reach the values of about $0.4-0.5 \mu_{\mathrm{B}}$ /atom.

ences between mean magnetic moments for distinct localizations of Al atoms are very small ( 0.087 and $0.080 \mu_{\mathrm{B}} / \mathrm{Co}$ atom for $\mathrm{BH}$ and $\mathrm{PW}$ potentials, respectively) and it is very difficult to admit them as conclusive for site preference of the impurities. Detailed analysis of X-ray diffraction patterns for $\mathrm{YCo}_{4} \mathrm{Al}$ and $\mathrm{NdCo}_{4} \mathrm{Al}$ systems [33] showed that distribution of $\mathrm{Al}$ on the $3 \mathrm{~g}$ and $2 \mathrm{c}$ sites of $\mathrm{CaCu}_{5}$-type structure is not quite random. The $\mathrm{Al}$ atoms prefer a little more the $3 \mathrm{~g}$ site than the $2 c$ one. However, for light rare-earth metals situation can be slightly different because of $4 f-3 d$ hybridization. The obtained rare-earth moments (for $\mathrm{Nd}$, $\mathrm{Pr}$, and Sm atoms) were considerably smaller than the free trivalent ion values. This discrepancy increases with increasing concentration of Al atoms and displays important role of $\mathrm{Al}(3 p)$ electrons in hybridization effects.

Second Co atom replaced by $\mathrm{Al}$ one in $\mathrm{GdCo}_{4} \mathrm{Al}$ intensifies the decrease in 
TABLE II

Total numbers of valence electrons (NOS; per f.u.) and individual contributions of the $\mathrm{Gd}, \mathrm{Co}$, and $\mathrm{Al}$ atoms to the electron count in the $\mathrm{GdCo}_{5}, \mathrm{GdCo}_{4} \mathrm{Al}$, and $\mathrm{GdCo}_{3} \mathrm{Al}_{2}$ compounds. The starting occupation numbers were the following: $\operatorname{Gd}\left(4 f^{7} 5 d^{1} 6 s^{2}\right), \operatorname{Co}\left(3 d^{7} 4 s^{2}\right)$, and $\mathrm{Al}\left(3 s^{2} 3 p^{1}\right)$.

\begin{tabular}{|c|c|c|c|c|c|c|}
\hline \multirow{4}{*}{$\begin{array}{l}\text { Positions } \\
\text { of atoms }\end{array}$} & \multicolumn{6}{|c|}{ Number of electrons per atom } \\
\hline & $\mathrm{GdCo}_{5}$ & \multicolumn{2}{|c|}{$\mathrm{GdCO}_{4} \mathrm{Al}$} & \multicolumn{3}{|c|}{$\mathrm{GdCo}_{3} \mathrm{Al}_{2}$} \\
\hline & \multicolumn{6}{|c|}{ Total NOS } \\
\hline & 55 & \multicolumn{2}{|c|}{49} & \multicolumn{3}{|c|}{43} \\
\hline \multirow{4}{*}{$3 g-1$} & Co & $\mathrm{Al}$ & Co & $\mathrm{Al}$ & $\mathrm{Al}$ & $\mathrm{Co}$ \\
\hline & $s 0.688$ & $s 0.953$ & $s 0.665$ & $s 0.955$ & $s 0.931$ & $s 0.656$ \\
\hline & $p 0.708$ & $p 1.299$ & $p 0.727$ & p 1.359 & $p 1.358$ & $p 0.784$ \\
\hline & $d 7.560$ & $d 0.315$ & $d 7.611$ & $d 0.312$ & $d 0.302$ & $d 7.669$ \\
\hline \multirow{4}{*}{$3 g-2$} & Co & Co & Co & $\mathrm{Al}$ & Co & Co \\
\hline & $s 0.6828$ & $s 0.696$ & $s 0.665$ & s 0.955 & $s 0.672$ & $s 0.657$ \\
\hline & $p 0.7076$ & $p 0.763$ & $p 0.727$ & $p 1.359$ & $p 0.773$ & $p 0.780$ \\
\hline & $d 7.5596$ & $d 7.633$ & $d 7.611$ & $d 0.312$ & $d 7.712$ & $d 7.669$ \\
\hline \multirow{4}{*}{$3 g-3$} & $\mathrm{Co}$ & $\mathrm{Co}$ & $\mathrm{Co}$ & $\mathrm{Co}$ & $\mathrm{Co}$ & $\mathrm{Co}$ \\
\hline & $s 0.688$ & $s 0.696$ & $s 0.665$ & $s 0.694$ & $s 0.672$ & $s 0.657$ \\
\hline & $p 0.708$ & $p 0.763$ & $p 0.727$ & $p 0.772$ & $p 0.773$ & $p 0.780$ \\
\hline & $d 7.560$ & $d 7.633$ & $d 7.611$ & $d 7.722$ & $d 7.712$ & $d 7.669$ \\
\hline \multirow{4}{*}{$2 \mathrm{c}-1$} & $\mathrm{Co}$ & $\mathrm{Co}$ & $\mathrm{Al}$ & $\mathrm{Co}$ & $\mathrm{Al}$ & $\mathrm{Al}$ \\
\hline & $s 0.664$ & $s 0.633$ & $s 0.964$ & $s 0.626$ & $s 0.945$ & $s 0.968$ \\
\hline & $p 0.647$ & $p 0.622$ & p 1.254 & $p 0.634$ & $p 1.272$ & $p 1.290$ \\
\hline & $d 7.585$ & $d 7.633$ & $d 0.330$ & $d 7.742$ & $d 0.290$ & $d 0.345$ \\
\hline \multirow{4}{*}{$2 \mathrm{c}-2$} & $\mathrm{Co}$ & $\mathrm{Co}$ & $\mathrm{Co}$ & $\mathrm{Co}$ & $\mathrm{Co}$ & $\mathrm{Al}$ \\
\hline & $s 0.664$ & $s 0.633$ & $s 0.705$ & $s 0.626$ & $s 0.669$ & $s 0.968$ \\
\hline & $p 0.647$ & $p 0.622$ & $p 0.718$ & $p 0.634$ & $p 0.698$ & $p 1.290$ \\
\hline & $d 7.585$ & $d 7.633$ & $d 7.656$ & $d 7.742$ & $d 7.701$ & $d 0.345$ \\
\hline \multirow{5}{*}{$1 \mathrm{a}$} & $\mathrm{Gd}$ & $\mathrm{Gd}$ & Gd & $\mathrm{Gd}$ & $\mathrm{Gd}$ & $\mathrm{Gd}$ \\
\hline & $s 0.591$ & $s 0.616$ & $s 0.586$ & $s 0.617$ & $s 0.602$ & $s 0.596$ \\
\hline & $p 0.725$ & $p 0.755$ & $p 0.724$ & $p 0.785$ & $p 0.765$ & $p 0.746$ \\
\hline & $d 1.724$ & $d 1.766$ & $d 1.766$ & $d 1.792$ & $d 1.833$ & $d 1.830$ \\
\hline & $f 7.300$ & $f 7.336$ & $f 7.289$ & $f 7.362$ & $f 7.320$ & $f 7.291$ \\
\hline
\end{tabular}

$\operatorname{DOS}\left(E=E_{\mathrm{F}}\right)$ but only in the case when at least one of the $\mathrm{Al}$ atoms is located in $3 \mathrm{~g}$ site: 5.159 states/(eV f.u.) for two $\mathrm{Al}$ atoms in $3 \mathrm{~g}$ sites and 7.486 states/(eV f.u.) for impurities simultaneously located in $3 \mathrm{~g}$ and $2 \mathrm{c}$ sites. The magnetic moments on Co atoms are reduced. Especially in the first case where mean magnetic moment on Co atoms is equal to $0.028 \mu_{\mathrm{B}}$ /atom, and Co moments located in $2 \mathrm{c}$ sites are parallel to the moments of Gd atoms. 
TABLE III

The values of the spin projected DOS at the Fermi level for the $\mathrm{GdCo}_{5}, \mathrm{GdCo}_{4} \mathrm{Al}$, and $\mathrm{GdCo}_{3} \mathrm{Al}_{2}$ compounds. The upper values concern the electrons with spin up and the lower ones the electrons with opposite spin direction (total DOS calculated per f.u.).

\begin{tabular}{|c|c|c|c|c|c|c|}
\hline \multirow{5}{*}{$\begin{array}{l}\text { Positions } \\
\text { of atoms }\end{array}$} & \multicolumn{6}{|c|}{ DOS $[$ states $/(\mathrm{eV}$ spin atom $)]$} \\
\hline & $\mathrm{GdCO}_{5}$ & \multicolumn{2}{|c|}{$\mathrm{GdCO}_{4} \mathrm{Al}$} & \multicolumn{3}{|c|}{$\mathrm{GdCo}_{3} \mathrm{Al}_{2}$} \\
\hline & \multicolumn{6}{|c|}{ Total DOS } \\
\hline & 14.290 & 11.295 & 7.341 & 2.202 & 5.022 & 13.051 \\
\hline & 1.520 & 0.741 & 1.213 & 2.957 & 2.464 & 1.489 \\
\hline \multirow{3}{*}{$3 g-1$} & $\mathrm{Co}$ & $\mathrm{Al}$ & $\mathrm{Co}$ & $\mathrm{Al}$ & $\mathrm{Al}$ & Co \\
\hline & 2.052 & 0.116 & 1.863 & 0.072 & 0.102 & 4.134 \\
\hline & 0.266 & 0.055 & 0.206 & 0.077 & 0.124 & 0.331 \\
\hline \multirow{3}{*}{$3 g-2$} & $\mathrm{Co}$ & Co & Co & $\mathrm{Al}$ & $\mathrm{Co}$ & Co \\
\hline & 2.052 & 2.794 & 1.863 & 0.072 & 1.617 & 4.134 \\
\hline & 0.266 & 0.148 & 0.206 & 0.077 & 0.608 & 0.331 \\
\hline \multirow{3}{*}{$3 g-3$} & $\mathrm{Co}$ & $\mathrm{Co}$ & $\mathrm{Co}$ & $\mathrm{Co}$ & $\mathrm{Co}$ & Co \\
\hline & 2.052 & 2.794 & 1.863 & 0.771 & 1.617 & 4.134 \\
\hline & 0.266 & 0.148 & 0.206 & 0.740 & 0.608 & 0.331 \\
\hline \multirow{3}{*}{$2 \mathrm{c}-1$} & $\mathrm{Co}$ & $\mathrm{Co}$ & $\mathrm{Al}$ & $\mathrm{Co}$ & $\mathrm{Al}$ & $\mathrm{Al}$ \\
\hline & 3.832 & 2.575 & 0.130 & 0.541 & 0.074 & 0.190 \\
\hline & 0.208 & 0.134 & 0.103 & 0.880 & 0.131 & 0.106 \\
\hline \multirow{3}{*}{$2 c-2$} & $\mathrm{Co}$ & $\mathrm{Co}$ & $\mathrm{Co}$ & $\mathrm{Co}$ & $\mathrm{Co}$ & $\mathrm{Al}$ \\
\hline & 3.832 & 2.575 & 1.389 & 0.541 & 1.389 & 0.190 \\
\hline & 0.208 & 0.134 & 0.255 & 0.880 & 0.661 & 0.106 \\
\hline \multirow{3}{*}{$1 \mathrm{a}$} & $\mathrm{Gd}$ & $\mathrm{Gd}$ & $\mathrm{Gd}$ & $\mathrm{Gd}$ & $\mathrm{Gd}$ & $\mathrm{Gd}$ \\
\hline & 0.470 & 0.441 & 0.233 & 0.205 & 0.223 & 0.269 \\
\hline & 0.306 & 0.122 & 0.237 & 0.303 & 0.332 & 0.284 \\
\hline
\end{tabular}

In the rest of the considered configurations Co moments are always antiparallel oriented to the Gd ones. The magnetic moments induced on $\mathrm{Al}$ atoms in this configuration reach the smallest values $\left(\approx 10^{-3} \mu_{\mathrm{B}}\right.$ /atom $)$. In the second case (two $\mathrm{Al}$ atoms simultaneously in $2 \mathrm{c}$ and $3 \mathrm{~g}$ sites) the Co magnetic moments are larger and reach values $0.4 \div 0.5 \mu_{\mathrm{B}} /$ atom (see Table IV). These values seem to be too high comparing with experimental measurements [18] which show that the Co moments should have values close to zero. Similar conclusion is for the case where two $\mathrm{Al}$ atoms are located in $2 \mathrm{c}$ sites. $\operatorname{DOS}\left(E_{\mathrm{F}}\right)$ reaches the highest value 14.54 states/(eV f.u.) and the Co magnetic moments are above $0.7 \mu_{\mathrm{B}} /$ atom. 
TABLE IV

The $a b$ initio calculated total (in $\mu_{\mathrm{B}}$ per f.u.) and local magnetic moments (in $\mu_{\mathrm{B}}$ per atom) for $\mathrm{GdCO}_{-x} \mathrm{Al}_{x}, x=0,1.0$ and 2.0, when the $\mathrm{Al}$ impurities are located in different crystallographic positions. The calculations were performed for two types of the exchange-correlation potential: $\mathrm{BH}$ and $\mathrm{PW}$ (the values in parenthesis).

\begin{tabular}{|c|c|c|c|c|c|c|}
\hline \multirow{3}{*}{$\begin{array}{l}\text { Positions } \\
\text { of atoms }\end{array}$} & \multicolumn{6}{|c|}{ Magnetic moments $\left[\mu_{\mathrm{B}} /(\right.$ f.u. or atom $\left.)\right]$} \\
\hline & \multirow{2}{*}{$\begin{array}{c}\mathrm{GdCo}_{5} \\
-0.038 \\
(-0.188) \\
\end{array}$} & \multicolumn{2}{|c|}{$\mathrm{GdCO}_{4} \mathrm{Al}$} & \multicolumn{3}{|c|}{$\mathrm{GdCo}_{3} \mathrm{Al}_{2}$} \\
\hline & & $\begin{array}{c}-3.027 \\
(-2.819) \\
\end{array}$ & $\begin{array}{c}-2.809 \\
(-2.636) \\
\end{array}$ & $\begin{array}{c}-7.069 \\
(-6.964) \\
\end{array}$ & $\begin{array}{c}-5.824 \\
(-5.169) \\
\end{array}$ & $\begin{array}{c}-5.000 \\
(-4.684) \\
\end{array}$ \\
\hline $3 g-1$ & $\begin{array}{c}\text { Co } 1.440 \\
(1.514) \\
\end{array}$ & $\begin{array}{c}\mathrm{Al}-0.073 \\
(-0.104)\end{array}$ & $\begin{array}{c}\text { Co } 1.091 \\
(1.170)\end{array}$ & $\begin{array}{l}\text { Al } 0.003 \\
(-0.001)\end{array}$ & $\begin{array}{c}\mathrm{Al}-0.017 \\
(-0.040)\end{array}$ & $\begin{array}{c}\text { Co } 0.727 \\
(0.883)\end{array}$ \\
\hline $3 g-2$ & $\begin{array}{c}\text { Co } 1.440 \\
(1.514)\end{array}$ & $\begin{array}{c}\text { Co } 1.098 \\
(1.191)\end{array}$ & $\begin{array}{c}\text { Co } 1.091 \\
(1.170)\end{array}$ & $\begin{array}{c}\text { Al } 0.003 \\
(-0.001)\end{array}$ & $\begin{array}{c}\text { Co } 0.384 \\
(0.660)\end{array}$ & $\begin{array}{c}\text { Co } 0.727 \\
(0.883)\end{array}$ \\
\hline $3 g-3$ & $\begin{array}{c}\text { Co } 1.440 \\
(1.514)\end{array}$ & $\begin{array}{c}\text { Co } 1.098 \\
(1.191)\end{array}$ & $\begin{array}{c}\text { Co } 1.091 \\
(1.170) \\
\end{array}$ & $\begin{array}{c}\text { Co } 0.049 \\
(0.152)\end{array}$ & $\begin{array}{c}\text { Co } 0.384 \\
(0.660)\end{array}$ & $\begin{array}{c}\text { Co } 0.727 \\
(0.883)\end{array}$ \\
\hline $2 c-1$ & $\begin{array}{c}\text { Co } 1.456 \\
(1.517) \\
\end{array}$ & $\begin{array}{c}\text { Co } 1.007 \\
(1.089) \\
\end{array}$ & $\begin{array}{c}\mathrm{Al}-0.082 \\
(-0.116)\end{array}$ & $\begin{array}{c}\text { Co }-0.066 \\
(-0.035)\end{array}$ & $\begin{array}{c}\mathrm{Al}-0.035 \\
(-0.064)\end{array}$ & $\begin{array}{c}\mathrm{Al}-0.041 \\
(-0.067)\end{array}$ \\
\hline $2 \mathrm{c}-2$ & $\begin{array}{c}\text { Co } 1.456 \\
(1.517)\end{array}$ & $\begin{array}{c}\text { Co } 1.007 \\
(1.089)\end{array}$ & $\begin{array}{c}\text { Co } 1.214 \\
(1.298)\end{array}$ & $\begin{array}{c}\text { Co }-0.066 \\
(-0.035)\end{array}$ & $\begin{array}{c}\text { Co } 0.524 \\
(0.797)\end{array}$ & $\begin{array}{c}\mathrm{Al}-0.041 \\
(-0.067)\end{array}$ \\
\hline $1 \mathrm{a}$ & $\begin{array}{c}\mathrm{Gd}-7.270 \\
(-7.388)\end{array}$ & $\begin{array}{c}\mathrm{Gd}-7.164 \\
(-7.275)\end{array}$ & $\begin{array}{c}\mathrm{Gd}-7.214 \\
(-7.328)\end{array}$ & $\begin{array}{c}\mathrm{Gd}-6.992 \\
(-7.044)\end{array}$ & $\begin{array}{c}\mathrm{Gd}-7.064 \\
(-7.182)\end{array}$ & $\begin{array}{c}\mathrm{Gd}-7.099 \\
(-7.199)\end{array}$ \\
\hline
\end{tabular}

\section{Conclusions}

A systematic study of magnetic moments of $\mathrm{GdCo}_{5}, \mathrm{GdCo}_{4} \mathrm{Al}$, and $\mathrm{GdCo}_{3} \mathrm{Al}_{2}$ compounds was performed using TB LMTO ASA method. The calculated results were compared with experimental data [18], which reported existence of a critical concentration of $\mathrm{Al}, x_{\mathrm{c}}=2$, for $\mathrm{GdCo}_{5} \mathrm{Al}_{x}$ when the Co sublattice becomes nonmagnetic. Our calculations showed strong dependence of magnetic properties of $\mathrm{GdCo}_{-x} \mathrm{Al}_{x}$ on concentration of $\mathrm{Al}$ and position of the impurities in the unit cell. To fulfil experimental observation of existence of the critical concentration the Al impurities should prefer $3 \mathrm{~g}$ sites otherwise the magnetic moments on Co atoms do not vanish.

\section{Acknowledgments}

The band calculations were performed in the Supercomputer and Networking Centre in Poznań (PCSS). 


\section{References}

[1] A. Szajek, J. Magn. Magn. Mater. 185, 322 (1998).

[2] A.T. Pedziwiatr, S.Y. Jiang, W.E. Wallace, E. Burzo, V. Pop, J. Magn. Magn. Mater. 66, 69 (1987).

[3] R. Tetean, E. Burzo, J. Magn. Magn. Mater. 157/158, 633 (1996).

[4] T. Ito, H. Asano, H. Ido, M. Yamada, J. Appl. Phys. 79, 5507 (1996).

[5] Yi Chen, Q.L. Liu, J.K. Liang, X.L. Chen, B.G. Shen, F. Huang, Appl. Phys. Lett. 74, 856 (1999).

[6] Yi Chen, J.K. Liang, X.L. Chen, X.L. Liu, J. Alloys Comp. 289, 96 (1999).

[7] Yi Chen, J.K. Liang, X.L. Chen, Q.L. Liu, B.G. Shen, Y.P. Shen, J. Phys., Condens. Matter 11, 8251 (1999).

[8] Yi Chen, X. Li, L. Chen, J.K. Liang, B.G. Shen, Q.L. Liu, Phys. Rev. B 61, 3502 (2000)

[9] K.H.J. Buschow, P.C.P. Bouten, A.R. Miedema, Rep. Prog. Phys. 45, 937 (1982).

[10] J.J.G. Willems, Philips J. Res. 36, 1 (1984).

[11] L. Schlapbach, in: Hydrogen in Intermetallic Compounds, II, Ed. L. Schlapbach, Springer, Berlin 1992, p. 165.

[12] A. Anani, A. Visintin, K. Petrov, S. Srinivasan, J.J. Reilly, J.R. Johnson, R.B. Schwarz, P.B. Desch, J. Power Sources 47, 261 (1994).

[13] J.-M. Joubert, R. Cerný, M. Latroche, A. Percheron-Guégan, K. Yvon, J. Appl. Crystallogr. 31, 327 (1998).

[14] J.-M. Joubert, R. Černý, M. Latroche, A. Percheron-Guégan, K. Yvon, J. Alloys Comp. 265, 311 (1998).

[15] A. Szajek, M. Jurczyk, W. Rajewski, J. Alloys Comp. 307, 290 (2000).

[16] C.Y. Tai, G.K. Marasinghe, G.D. Waddill, O.A. Pringle, W.J. James, J. Appl. Phys. 87, 6731 (2000).

[17] J.B. Yang, C.Y. Tai, G.K. Marasinghe, G.D. Waddill, O.A. Pringle, W.J. James, Y. Kong, Phys. Rev. B 63, 014407 (2001).

[18] H. Ido, K. Konno, S.F. Cheng, W.E. Wallace, S.G. Sanker, J. Appl. Phys. 67, 4638 (1990).

[19] O.K. Andersen, O. Jepsen, M. Šob, in: Electronic Structure and Its Applications, Ed. M.S. Yussouff, Springer, Berlin 1987, p. 2.

[20] G. Krier, O. Jepsen, A. Burkhardt, O.K. Andersen, The TB-LMTO-ASA program, source code, version 4.7, available upon request from the program authors.

[21] B.I. Min, Y.-R. Jang, J. Phys., Condens. Matter 3, 5131 (1991).

[22] U. von Barth, L. Hedin, J. Phys. C 5, 1629 (1972).

[23] J.P. Perdew, J.A. Chevary, S.H. Vosko, K.A. Jackson, M.R. Pederson, D.J. Singh, C. Fiolhais, Phys. Rev. B 46, 6671 (1992).

[24] O. Jepsen, O.K. Andersen, Solid State Commun. 9, 1763 (1971).

[25] O. Jepsen, O.K. Andersen, Phys. Rev. B 29, 5965 (1984).

[26] P. Blöchl, O. Jepsen, O.K. Andersen, Phys. Rev. B 49, 16223 (1994). 
[27] E. Gurewitz, H. Pinto, M. Dariel, H. Shaked, J. Phys. F, Met. Phys. 13, 545 (1983).

[28] K. Hummler, M. Fähnle, Phys. Rev. B 53, 3272 (1996).

[29] F.M. Mulder, R. Coehoorn, R.C. Thiel, K.H.J. Buschow, Phys. Rev. B 56, 5786 (1997).

[30] V.V. Aleksandryan, K.P. Belov, P.Z. Levitin, A.S. Markosyan, W.W. Snegirev, Pis'ma Zh. Eksp. Teor. Fiz. 40, 77 (1984).

[31] I. Shidlovsky, W.E. Wallace, J. Solid State Chem. 2, 193 (1970).

[32] C.V. Thang, N.H. Duc, M.M. Tan, N.P. Thuy, E. Brück, P.E. Brommer, J.J.M. Franse, J. Magn. Magn. Mater. 177-181, 819 (1998).

[33] K. Konno, H. Ido, S.F. Cheng, S.G. Sanker, W.E. Wallace, J. Appl. Phys. 73, 5929 (1993). 